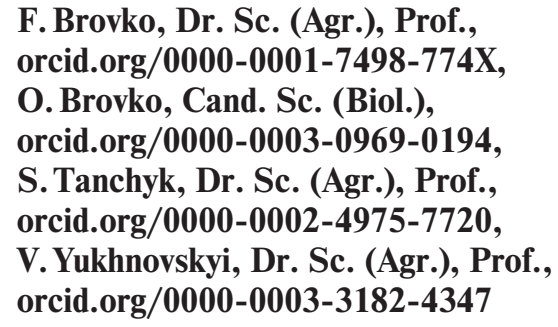

\title{
OPTIMIZATION OF WATER-PHYSICAL PROPERTIES OF SANDY SOILS OF NATURAL-TECHNOGENIC ORIGIN
}

Purpose. To establish the changes in the water-physical properties of sandy soils under the influence of different content of forest-like loam, humus mass of sod-podzolic sandy loam and gray loamy soils and to show their influence on the phytomass production of annual seedlings of Scotch pine and common oak.

Methodology. Indicators of density, porosity, as well as absolute and relative humidity of sandy soils and their mixtures with different content of loam and humus mass of zonal soils were determined by conventional methods in soil science. The effect of the studied mixtures on the water-physical properties of the sands was evaluated by the parameters of accumulated absolutely dry phytomass of annual pine seedlings and seedlings of common oak.

Findings. It is established that with increasing the content of forest loam and humus mass in sandy and sod-podzolic sandy soils from 20 to $80 \%$ in their mixtures there is observed decrease in density (by 3.4-24.8\%), increase in porosity (by $1.1-70.0 \%$ ) and humidity - absolute (at 5-560\%) and relative (at 11-442\%). The share of needles in the total phytomass of pine seedlings is increasing (by 2-8\%), and the share of roots is decreasing (by 2-18\%). One-year-old pine seedlings accumulated the largest mass $(2539 \mathrm{mg}$ ) on a mixture with $20 \%$ of humus mass content and $80 \%$ of loam content. With the increase in the sand content of forest loams and humus mass of gray forest loam soils from 20 to $80 \%$ absolute humidity of the mixtures increases by $75.0-870.0 \%$, and the relative humidity - by 61.0-639.0\%. In the total phytomass of annual oak seedlings, the part of leaves increases (by $11.9-15.8 \%$ ), and the proportion of roots decreases (by 13.0-22.8\%). In annual oak seedlings, maximum values of the total mass $(10.7 \mathrm{~g})$ were observed on mixtures containing $40 \%$ of humus mass of gray forest soils, $20 \%$ of loess loam and $40 \%$ sand, as well as $80 \%$ of humus mass and $20 \%$ of loam.

Originality. It is shown that $20-80 \%$ of admixture to the sands of loess loam and humus mass of sod-podzolic sandy soils significantly increases their porosity, their moisture content and has a positive effect on the accumulation of phytomass in annual pine seedlings. The same admixture to the sands of loess loams and humus mass of gray forest loamy soil provides a significant increase in absolute and relative humidity in the studied mixtures and causes oak seedlings to increase the mass of leaves and reduce the mass of roots in annual seedlings.

Practical value. The proposed variants of formation of recultivation layer of three-component mixtures, which include sand, loess loam and humus mass of zonal soils allow optimizing the water-physical properties of sandy soils of natural-technogenic origin. The use of treated soil mixtures will ensure a more efficient use of man-made landscapes for economic purposes and at the same time reduce the manifestation of water erosion and deflation.

Keywords: phytomass, loess loam, humus mass, seedling, density, porosity

Introduction. Within Ukraine, sand deposits are found among the overburden of most quarrying deposits, and almost all anthropogenically disturbed landscapes are formed in the floodplains of Polissia rivers. There are about 120 thousand hectares of such sands [1, 2]. Due to their low water-holding capacity (4-6\%), atmospheric precipitation seeps to water table and is not able to rise up due to poor capillarity. Therefore, the productivity of phytocenoses on sands is determined by abiotic factors, and, in particular, the content of physical clay, since the increase of phytomass in woody plants is directly proportional to the increase of this component in the sands. Improvement of biological stability of woody plants on sandy soils is possible due to increase in their content of physical clay or transfer to such areas of humus mass of forest soils inherent in natural stands that are supposed to be grown on sandy landscapes [3, 4].

To provide environmental safety on man-made landscapes [5, 6], and suggest planting native plants [7] scientists monitor the soils and rocks from which they are formed $[5,6]$ to reproduce forest ecosystems. At present, it has been found that for the cultivation of forest plantations on sandy soils for phytomelioration purposes, the capacity of the reculivation layer should be $80-140 \mathrm{~cm} \mathrm{[8].}$

It has been proposed to use peat-mineral mixtures with and without fertilizer application for the recultivation of sands

(C) Brovko F., Brovko O., Tanchyk S., Yukhnovskyi V., 2020
[9], as well as the method of reclamation of sands without application of peat-sand mixture on their surface [10], which allows reducing the costs of the biological stage of their reclamation. In the absence of humus and other genetically determined horizons, sandy soils are among the most extreme trophycal type of pine sites. The sands are deflated and pollute the environment with the products of water and wind erosion, which is why their phytomelioration still belongs to the current environmental problems of today.

Literature review. In recent years, scientists involved in the field of forestry development of sandy soils have found that in the case of natural development of biota on technogenically disturbed landscapes restoration of their evolutionarily balanced physical parameters, in particular, such as density, porosity and water content are delayed for decades [11]. Their research shows that the most effective use of humus mass stored in disturbed territories in combination with the natural regeneration of woody plants is the most effective use of sand reclamation $[12,13]$. However, the lack of humus or its absence, against the backdrop of unsatisfactory water regime of the sands, encourage scientists to look for methods for assessing the risks associated with their ecological restoration [14], which provide for comprehensive studies, in particular, such as ecohydrological optimization with attraction remote sensing [15], elaboration of methods of moisture retention and water conservation in the recultivation layer of sands $[3,16]$ and ap- 
plication of biocementation for cell surface by halotolerant bacteria [17], as well as identification of wood species that can successfully cultivate under such growth conditions [18]. These studies open up great opportunities to improve the edaphic conditions of the reclamation layer of sands provided they are forested. However, the local topographic features of individual sandy landscapes complicate the ecological situation and against the background of differences in the fertility and water content of the sands, there is an urgent need for scientific justification for the feasibility of their reclamation.

Unsolved aspects of the problem. The use of two-component mixtures to improve the reclamation layer of sandy soils and the forest sites properties has a positive effect on their water and physical properties. In particular, in the case of admixture to the sand of the humus mass of sod-podzolic sandy soils, there is a partial enrichment of the mixture with organic matter, but there is no significant improvement of their water-physical properties. In the case when loess loam is mixed with sand in the volume of $60-80 \%$, a favorable mode of moistening is provided. However, it is worth noting that sand, with a content of loams in their composition of more than $60 \%$, is characterized by poor water permeability and such mixtures are not able to effectively absorb water during heavy rains and effectively prevent the development of erosion processes. Insignificant moisture content, combined with excessively high permeability of the humus mass of sod-podzolic sandy loam soils and poor water permeability and air regime of the loamy loams reduce the phytomeliorative effect of the formation of edaphotopes with their participation which includes sand, loess loam, and a humus mass of zonal soils. To investigate the effect of these ameliorants on the alteration of the water properties of the sands and the phytomass accumulation by woody plants, this study was conducted.

Purpose. The main task of the study is to determine the optimal parameters of the composition of mixtures for the formation of the reclamation layer of technogenically disturbed landscapes during the application of forestry direction of reclamation.

Methods. The study was carried out on two variants with the use as soil ameliorants of humus mass of sod-podzolic sandy loam soils and loess loams (for cultivation on the sands of oligotrophs plants, for example, annual seedlings of Scotch pine) and humus mass of gray forest loam and loess loam soils (for cultivation of mesotrophs, on the example of annual seedlings of common oak). The influence of these ameliorants on the formation of the basic water-physical properties of sandy soils was investigated at a dump, which was formed by hydro accumulation involving dredgers on the left bank of the Dnipro River (south of "Osokorky" underground station, Kyiv). The height of the dump is $6-8 \mathrm{~m}$, the area is more than 30 hectares. Its modern contours were formed in 1999, and the research was conducted in 2015 during the growing season. The experiments used a humus mass of the upper $5 \mathrm{~cm}$ layer of sod-podzolic sandy loam, harvested in mature pine-hazel stand of Mezhyhir forestry and gray forest loamy soil, harvested in mature oakhornbeam stand of Holosiivo forestry as well as loess loam taken of 5-meter depth of island loess (Khotiv village, Kyiv region). The pits $30 \mathrm{~cm}$ deep and $50 \mathrm{~cm}$ in diameter were equipped in the sandy soil in mid-April. The sand, taken of the pits on plastic wrap after mixing with the ameliorants in pre-set proportions was again poured back into the pits in level with the day surface of the dump. In the experiments with the threecomponent mixtures, the sand was mixed with loam and humus mass according to the $21^{\text {st }}$ variant in the following ratios: $1-100-0-0 \%$ (control); $2-80-20-0 \% ; 3-60-40-0 \%$; $4-40-60-0 \% ; 5-20-80-0 \% ; 6-0-100-0 \% ; 7-$ $80-0-20 \% ; 8-60-20-20 \% ; 9-40-40-20 \% ; 10-20-$ $60-20 \% ; 11-0-80-20 \% ; 12-60-0-40 \% ; 13-40-20-$ $40 \% ; 14-20-40-40 \% ; 15-0-60-40 \% ; 16-40-0-60 \%$; $17-20-20-60 \% ; 18-0-40-60 \% ; 19-20-0-80 \% ; 20-$ $0-20-80 \% ; 21-0-0-100 \%$. The repetition of experiments is 3 -fold. Five seedlings sorted by biometric parameters of pine plants were planted in each equipped pit with a humus mass of sod-podzolic soil. The five pre-calibrated by weight $(5-6 \mathrm{~g})$ incubated acorns of common oak were sown in the variant with the use of gray forest soils. The data were collected at the end of October. The phytomeliorative effect of sandy soils with the admixture of ameliorants was evaluated by the phytomass of 1 -year-old pine seedlings and 1-year-old oak seedlings. Density was determined in $\mathrm{g}^{\circ} \mathrm{cm}^{-3}$, and the porosity, absolute and relative humidity of sandy soils and mixtures with the participation of ameliorants were determined in volume percent by the core method $[19,20]$. Absolutely dry phytomass of the test seedlings was determined by weighing on the laboratory electronic scales of TV 404316.002 TE after drying in a thermostat (at $105^{\circ} \mathrm{C}$ ) of individual vegetative organs in 11 experimental plants of each variant. The average data obtained and the statistical significance of the difference between the studied data (Student's $t$ test) were calculated using the STATISTICA application program [21].

Results. The success of the growth and development of woody plants on sandy soils is largely related to their density and porosity, and depends on a complex of factors, among which the leading place lies in the ability of the roots of woody plants to penetrate into sandy thickness, as well as its availability of productive moisture. The ameliorants used to improve the forest plant properties were significantly different from the sands in density and porosity (Table 1).

Table 1

Density and porosity of sandy soils with different admixture of humus mass of sod-podzolic soils and loess loam

\begin{tabular}{|c|c|c|c|c|c|c|c|}
\hline \multicolumn{2}{|c|}{ Content, $\%$} & \multicolumn{3}{|c|}{ Density } & \multicolumn{3}{|c|}{ Porosity } \\
\hline \multirow{2}{*}{$\underset{E}{E}$} & \multirow{2}{*}{$\begin{array}{l}\text { E్ } \\
\text { 。్ }\end{array}$} & \multirow{2}{*}{$\mathrm{g} \cdot \mathrm{cm}^{-3}$} & \multicolumn{2}{|c|}{$\begin{array}{l}\text { regarding } \\
\text { control }\end{array}$} & \multirow[t]{2}{*}{$\%$} & \multicolumn{2}{|c|}{$\begin{array}{l}\text { regarding } \\
\text { control }\end{array}$} \\
\hline & & & $\%$ & $t_{p}$ & & $\%$ & $t_{p}$ \\
\hline \multicolumn{8}{|c|}{ Without humus mass } \\
\hline 100 & 0 & $1.49 \pm 0.01$ & 100.0 & - & $18.80 \pm 0.01$ & 100.0 & - \\
\hline 80 & 20 & $1.50 \pm 0.02$ & 100.7 & 0.4 & $19.11 \pm 0.10$ & 101.6 & 3.1 \\
\hline 60 & 40 & $1.52 \pm 0.02$ & 102.0 & 1.3 & $20.05 \pm 0.24$ & 106.6 & 5.2 \\
\hline 40 & 60 & $1.53 \pm 0.02$ & 102.6 & 1.8 & $21.07 \pm 0.16$ & 112.1 & 14.2 \\
\hline 20 & 80 & $1.55 \pm 0.02$ & 104.0 & 2.9 & $22.40 \pm 0.31$ & 119.2 & 11.6 \\
\hline 0 & 100 & $1.56 \pm 0.02$ & 104.7 & 10.5 & $22.17 \pm 0.26$ & 117.9 & 12.9 \\
\hline \multicolumn{8}{|c|}{ Humus mass $20 \%$} \\
\hline 80 & 0 & $1.40 \pm 0.02$ & 94.0 & 1.3 & $19.00 \pm 0.07$ & 101.1 & 2.6 \\
\hline 60 & 20 & $1.41 \pm 0.01$ & 94.6 & 1.8 & $23.04 \pm 0.27$ & 122.0 & 15.6 \\
\hline 40 & 40 & $1.42 \pm 0.01$ & 95.3 & 1.6 & $26.13 \pm 0.35$ & 139.0 & 20.9 \\
\hline 20 & 60 & $1.44 \pm 0.01$ & 96.6 & 1.1 & $25.39 \pm 0.21$ & 135.0 & 31.0 \\
\hline 0 & 80 & $1.49 \pm 0.01$ & 100.0 & 0 & $24.07 \pm 0.11$ & 128.0 & 46.0 \\
\hline \multicolumn{8}{|c|}{ Humus mass $40 \%$} \\
\hline 60 & 0 & $1.33 \pm 0.02$ & 89.3 & 2.3 & $19.25 \pm 0.08$ & 102.4 & 5.2 \\
\hline 40 & 20 & $1.35 \pm 0.01$ & 90.6 & 3.1 & $27.03 \pm 0.29$ & 143.8 & 28.1 \\
\hline 20 & 40 & $1.36 \pm 0.01$ & 91.3 & 2.9 & $31.75 \pm 0.12$ & 168.9 & 104.4 \\
\hline 0 & 60 & $1.38 \pm 0.01$ & 92.6 & 2.5 & $30.43 \pm 0.16$ & 161.9 & 71.3 \\
\hline \multicolumn{8}{|c|}{ Humus mass $60 \%$} \\
\hline 40 & 0 & $1.23 \pm 0,02$ & 82.6 & 3.7 & $19.91 \pm 0.34$ & 105.9 & 3.2 \\
\hline 20 & 20 & $1.27 \pm 0,01$ & 85.2 & 4.9 & $26.20 \pm 0.33$ & 139.4 & 22.3 \\
\hline 0 & 40 & $1.30 \pm 0,01$ & 87.2 & 4.2 & $31.97 \pm 0.10$ & 170.0 & 125.6 \\
\hline \multicolumn{8}{|c|}{ Humus mass $80 \%$} \\
\hline 20 & 0 & $1.12 \pm 0.02$ & 75.2 & 5.2 & $20.30 \pm 0.54$ & 108.0 & 2.8 \\
\hline 0 & 20 & $1.18 \pm 0.01$ & 79.2 & 6.9 & $26.41 \pm 0.46$ & 140.5 & 16.5 \\
\hline \multicolumn{8}{|c|}{ Without sand and loam } \\
\hline 0 & $0^{*}$ & $1.09 \pm 0.02$ & 73.2 & 5.7 & $20.54 \pm 0.08$ & 109.2 & 20.1 \\
\hline
\end{tabular}

Note. Table value of quantiles of Student's $t$ test $(t)$ at probability level $0.05-2.45$ 
In particular, loess loam was characterized by a higher density (by $4.7 \%$ ) and porosity (by $17.9 \%$ ) than sand, which was due to the higher content of silt fractions and the absence of long-lasting influence of vegetation on them. The humus mass of sod-podzolic soils was characterized by a lower density (by $21.8 \%$ ) and a higher porosity (by $9.2 \%$ ), which was caused by the formation of a humus mass of this ameliorant under the influence of vegetation cover and the presence of organic and mineral substances in it, as well as microorganisms. It should be noted that in two-component mixtures with increasing content of loam in the sand from 20 to $80 \%$, the density of the mixtures increased by $0.7-4.0 \%$. Significant differences were acquired only in the mixture containing $80 \%$ of loam with increasing the porosity by $1.6-19.2 \%$. The lowest density, which was $24.8 \%$ less than the control, was observed in the mixture with $80 \%$ content of humus and $20 \%$ sand, and the highest porosity (70\% higher than the control) was observed in the mixture containing $60 \%$ humus mass and $40 \%$ loam. In the three-component mixtures, the lowest density (less than $24.8 \%$ than the control) was observed in the mixtures containing $60 \%$ of the humus and $20 \%$ of sand and loam, and the highest values of the porosity (68.9\% higher than the controls) occurred in a mixture with $40 \%$ humus content of sod-podzolic soils, $20 \%$ sand and $40 \%$ loam. It should also be noted that loess loams and $20 \%$ admixture of humus soil of sod-podzolic soils are not able to significantly improve the density of the test mixtures ( $t_{p}=$ up to 1.8 ), but significantly affect their porosity $\left(t_{p}=2.6-46.0\right)$ which indicates the appropriateness of using them to improve the forest vegetation properties of the sands.

The mode of moistening of the sands, which were mixed with loam and humus mass, depended on the share of participation in the mixtures of these ameliorants. The regime of moistening of the sands, which were mixed with loam and humus mass, depended on the share of participation in the mixtures of these ameliorants (Table 2). In all variants, except where the sands contained a $20 \%$ admixture of the humus mass of sod-podzolic soils, a significant difference was observed between the absolute and relative moisture content of the sands and the mixtures studied, which gives reason to consider these mixtures as likely variants to be used to improve the water properties of the sands.

In the two-component mixtures, the greatest ability to accumulate and retain both absolute and relative moisture was demonstrated by a mixture in which $20 \%$ of the sands were combined with $80 \%$ of loess loams. Among the tested threecomponent mixtures, the best moistening mode was observed in the variant, where $20 \%$ of the humus mass of sod-podzolic soils were combined with $20 \%$ of sand and $60 \%$ of loess loams. It is this mixture that should be recommended for optimization of the water regime of the recultivation layer of sandy soils on which oligotrophs are supposed to cultivate.

In variants where loess loam and humus mass of gray forest loamy soils have been applied as ameliorants, the tendencies observed in mixtures with the content of humus soil of sodpodzolic soils have been preserved. At the same time, against the background of increased content of silt fractions and organic substances in the components used, the manifestation of differences increased as evidenced by the data given in Table 2 .

Thus, in the two-component mixtures, the highest humidity values occurred in the mixture containing $20 \%$ of the humus mass and $80 \%$ of the loess loam. In this case, the absolute moisture content of this mixture was $63 \%$, and the relative humidity was $39 \%$ higher than the highest values recorded in mixtures containing an admixture of humus of sod-podzolic soils. In the three-component mixtures, the highest moisture content was observed in the mixture containing $20 \%$ of humus mass, $20 \%$ of sand and $60 \%$ of loess loam. The moisture content was dominated by controls in this mixture: by absolute humidity in $735 \%$ and relative humidity by $450 \%$. This mixture can serve as a base in the case of improvement of the water
Table 2

Humidity of sandy soils with different admixture of loam and humus mass of zonal soils ( $\%$ by volume)

\begin{tabular}{|c|c|c|c|c|c|c|c|}
\hline \multicolumn{2}{|c|}{ Content. \% } & \multicolumn{3}{|c|}{ Humidity absolute } & \multicolumn{3}{|c|}{ Humidity relative } \\
\hline \multirow{2}{*}{ 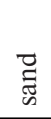 } & \multirow{2}{*}{ 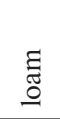 } & \multirow{2}{*}{$\%$} & \multicolumn{2}{|c|}{$\begin{array}{l}\text { regarding } \\
\text { control }\end{array}$} & \multirow[t]{2}{*}{$\%$} & \multicolumn{2}{|c|}{$\begin{array}{l}\text { regarding } \\
\text { control }\end{array}$} \\
\hline & & & $\%$ & $t_{p}$ & & $\%$ & $t_{p}$ \\
\hline \multicolumn{8}{|c|}{ Without humus mass } \\
\hline 100 & 0 & $2.0 \pm 0.15$ & 100 & - & $10.1 \pm 0.09$ & 100 & - \\
\hline 80 & 20 & $3.7 \pm 0.11$ & 185 & 9.1 & $17.4 \pm 0.06$ & 172 & 67.5 \\
\hline 60 & 40 & $7.4 \pm 0.10$ & 370 & 30.0 & $26.4 \pm 0.10$ & 261 & 12.2 \\
\hline 40 & 60 & $11.3 \pm 0.09$ & 565 & 53.2 & $38.9 \pm 0.12$ & 385 & 192.0 \\
\hline 20 & 80 & $16.3 \pm 0.07$ & 815 & 86.4 & $62.0 \pm 0.15$ & 614 & 296.7 \\
\hline 0 & 100 & $20.7 \pm 0.44$ & 1035 & 40.2 & $93.3 \pm 0.28$ & 924 & 282.3 \\
\hline \multicolumn{8}{|c|}{ The content of the humus mass of sod-podzolic soils: } \\
\hline \multicolumn{8}{|c|}{$20 \%$} \\
\hline 80 & 0 & $2.1 \pm 0.05$ & 105 & 0.6 & $11.2 \pm 0.23$ & 111 & 4.5 \\
\hline 60 & 20 & $2.8 \pm 0.07$ & 140 & 4.8 & $12.2 \pm 0.18$ & 121 & 10.4 \\
\hline 40 & 40 & $5.0 \pm 0.16$ & 250 & 13.7 & $19.1 \pm 0.41$ & 189 & 21.4 \\
\hline 20 & 60 & $8.1 \pm 0.08$ & 405 & 35.9 & $31.7 \pm 0.31$ & 314 & 66.9 \\
\hline 0 & 80 & $13.2 \pm 0.18$ & 660 & 47.8 & $54.8 \pm 0.81$ & 542 & 54.8 \\
\hline \multicolumn{8}{|c|}{$40 \%$} \\
\hline 60 & 0 & $2.4 \pm 0.08$ & 120 & 2.4 & $11.7 \pm 0.36$ & 116 & 3.4 \\
\hline 40 & 20 & $3.4 \pm 0.08$ & 170 & 7.1 & $12.5 \pm 0.24$ & 124 & 9.4 \\
\hline 20 & 40 & $6.7 \pm 0.06$ & 335 & 29.1 & $21.2 \pm 0.11$ & 210 & 78.1 \\
\hline 0 & 60 & $11.9 \pm 0.12$ & 595 & 51.5 & $39.1 \pm 0.31$ & 387 & 89.8 \\
\hline \multicolumn{8}{|c|}{$60 \%$} \\
\hline 40 & 0 & $2.6 \pm 0.07$ & 130 & 3.6 & $13.3 \pm 0.20$ & 132 & 14.6 \\
\hline 20 & 20 & $3.9 \pm 0.04$ & 191 & 12.2 & $14.8 \pm 0.29$ & 145 & 15.5 \\
\hline 0 & 40 & $8.6 \pm 0.13$ & 430 & 33.2 & $26.8 \pm 0.45$ & 265 & 95.5 \\
\hline \multicolumn{8}{|c|}{$80 \%$} \\
\hline 20 & 0 & $2.8 \pm 0.05$ & 140 & 5.1 & $13.5 \pm 0.15$ & 134 & 19.4 \\
\hline 0 & 20 & $4.1 \pm 0.07$ & 205 & 12.7 & $15.5 \pm 0.18$ & 153 & 26.8 \\
\hline \multicolumn{8}{|c|}{ Without sand and loam } \\
\hline 0 & 0 & $2.9 \pm 0.12$ & 145 & 4.7 & $14.2 \pm 0.09$ & 140 & 32.2 \\
\hline \multicolumn{8}{|c|}{ The content of the humus mass of sod-podzolic soils } \\
\hline \multicolumn{8}{|c|}{$20 \%$} \\
\hline 80 & 0 & $3.5 \pm 0.11$ & 175 & 8.1 & $16.3 \pm 0.05$ & 161 & 60.2 \\
\hline 60 & 20 & $5.0 \pm 0.16$ & 250 & 13.7 & $22.3 \pm 0.06$ & 221 & 112.8 \\
\hline 40 & 40 & $10.3 \pm 0.13$ & 515 & 41.8 & $33.8 \pm 0.06$ & 335 & 219.1 \\
\hline 20 & 60 & $14.7 \pm 0.11$ & 735 & 68.3 & $45.4 \pm 0.13$ & 450 & 223.3 \\
\hline 0 & 80 & $19.8 \pm 0.10$ & 990 & 98.7 & $74.6 \pm 0.19$ & 739 & 306.8 \\
\hline \multicolumn{8}{|c|}{$40 \%$} \\
\hline 60 & 0 & $5.8 \pm 0.14$ & 290 & 13.6 & $22.1 \pm 0.11$ & 219 & 84.4 \\
\hline 40 & 20 & $8.2 \pm 0.13$ & 410 & 31.2 & $28.4 \pm 0.20$ & 281 & 83.4 \\
\hline 20 & 40 & $13.8 \pm 0.14$ & 690 & 57.5 & $41.6 \pm 0.10$ & 412 & 234.1 \\
\hline 0 & 60 & $19.4 \pm 0.09$ & 970 & 99.5 & $54.3 \pm 0.18$ & 538 & 219.6 \\
\hline & & & & $\%$ & & & \\
\hline 40 & 0 & $8.1 \pm 0.14$ & 405 & 29.7 & $29.6 \pm 0.08$ & 293 & 149.5 \\
\hline 20 & 20 & $12.1 \pm 0.08$ & 605 & 59.4 & $35.6 \pm 0.08$ & 352 & 195.5 \\
\hline 0 & 40 & $17.8 \pm 0.05$ & 890 & 99.9 & $49.3 \pm 0.13$ & 488 & 347.9 \\
\hline & & & & $\%$ & & & \\
\hline 20 & 0 & $11.4 \pm 0.12$ & 570 & 48.9 & $37.1 \pm 0.12$ & 367 & 180.0 \\
\hline 0 & 20 & $16.4 \pm 0.12$ & 820 & 75.0 & $43.1 \pm 0.09$ & 427 & 259.3 \\
\hline & & & houts & id and & oam & & \\
\hline 0 & 0 & $15.1 \pm 0.14$ & 755 & 63.8 & $46.7 \pm 0.08$ & 462 & 280.6 \\
\hline
\end{tabular}

Note. Table value of quantiles of Student's $\mathrm{t}$ test $(\mathrm{t})$ at probability level $0.05-2.45$ 
regime of the recultivation layer of sandy soils, which are intended to grow mesotrophic woody plants.

The ameliorants used to improve the forest vegetation properties of the sands did not have a clear impact on the growth and development of the investigated woody plants. One-year-old pine seedlings grown on mixtures with an admixture of humus mass of sod-pod-podzolic soils, in the structure of the skeleton of the root systems preserved characteristic features inherent in sandy soils. Visually visible mycorrhizal spots were formed on their roots by the end of the growing season (Fig. 1). Their maximum mass (13-15\% of the total mass of seedlings) was observed on the roots of the seedlings, which grew on mixtures with $20-40 \%$ content of humus mass.

Considering the effect of two-component mixtures on the accumulation of phytomass by pine seedlings, it should be noted that with the increase in the content of loams (from 20 to $80 \%$ ) in the sands, the total mass of plants increased significantly (Table 3 ).

At the same time, the share of needles in it increased by $8 \%$, the share of roots decreased by $11 \%$, and maximum values of the total mass of seedlings and the mass of their above-ground organs were recorded in the variant where $20 \%$ of sands were combined with $80 \%$ of loam. The maximum root mass was fixed on a mixture containing $40 \%$ loam and $60 \%$ sand.

Among the two-component mixtures containing humus mass, it is necessary to note a mixture containing $20 \%$ of humus mass and $80 \%$ of loam, as it is on this mixture that pine seedlings accumulated the largest total mass, which exceeded the weight of control seedlings by $308 \%$. On the three-component mixtures, the largest total mass was also observed in pine seedlings growing on a mixture of $20 \%$ humus mass and sand content and $60 \%$ loam content. That allows us to recommend that we limit ourselves to a $20 \%$ admixture of humus mass of sod-podzolic soils. In general, as the sand content of the land reclaimed increases, the total mass of pine seedlings increases significantly. The proportion of needles increases (by 2-8\%) and the proportion of roots decreases (by 2-18\%). From the given data it is clear that in case of oligotrophs growing on sandy soils, for optimization of ecological properties of their reclamation layer it is necessary to offer a two-component mixture consisting of $20 \%$ of humus mass of sod-podzolic soils and $80 \%$ of loess loam and of three-component mixture that contain $20 \%$ of the humus mass of sod-podzolic soils, $20 \%$ of sand and $60 \%$ of loess loams.

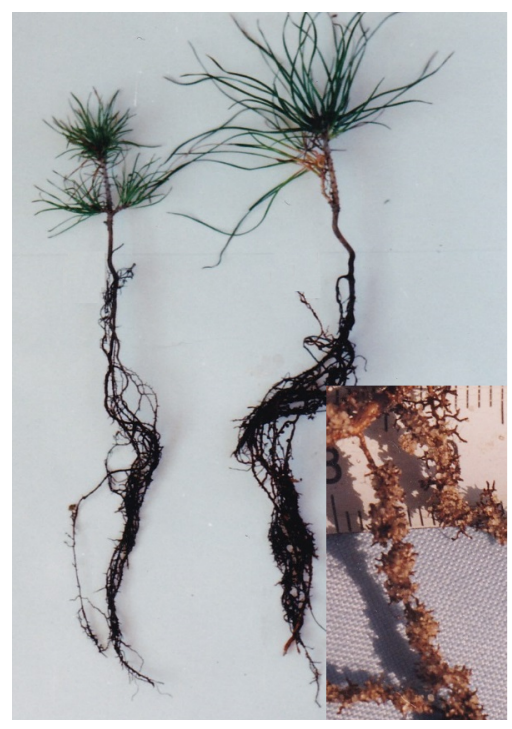

Fig. 1. Annual pine seedlings grown on sandy soils (left) and on a mixture of sands (40\%), humus mass of sod-podzolic soils $(20 \%)$ and loess loams (40\%) (right). Fragment of mycorrhizal spots formed on the roots (bottom right)
Table 3

Phytomass of annual pine seedlings, grown on sandy soils with different content of humus mass of sod-podzolic and loess loam

\begin{tabular}{|c|c|c|c|c|c|c|c|}
\hline \multicolumn{2}{|c|}{ Content, $\%$} & \multicolumn{4}{|c|}{ Mass, mg } & \multicolumn{2}{|c|}{ Mass, $\%$} \\
\hline 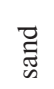 & छ్ & stems & needle & roots & total & $\begin{array}{l}\stackrel{\mathscr{Z}}{\vec{J}} \\
\stackrel{\Xi}{\Xi}\end{array}$ & 。ั \\
\hline \multicolumn{8}{|c|}{ Without humus mass } \\
\hline 100 & 0 & $\frac{80 \pm 3}{100--}$ & $\frac{348 \pm 12}{100-}$ & $\frac{396 \pm 9}{100--}$ & $\frac{824 \pm 21}{100--}$ & 42 & 48 \\
\hline 80 & 20 & $\frac{230 \pm 6}{288-22}$ & $\frac{571 \pm 14}{164-12}$ & $\frac{582 \pm 16}{147-10}$ & $\frac{1383 \pm 34}{168-14}$ & 41 & 42 \\
\hline 60 & 40 & $\frac{365 \pm 12}{456-23}$ & $\frac{760 \pm 28}{218-14}$ & $\frac{690 \pm 23}{174-12}$ & $\frac{1815 \pm 62}{220-15}$ & 42 & 38 \\
\hline 40 & 60 & $\frac{440 \pm 10}{550-34}$ & $\frac{921 \pm 25}{265-21}$ & $\frac{673 \pm 13}{170-18}$ & $\frac{2034 \pm 47}{247-24}$ & 45 & 33 \\
\hline 20 & 80 & $\frac{433 \pm 12}{541-28}$ & $\frac{1040 \pm 41}{299-16}$ & $\frac{650 \pm 20}{164-12}$ & $\frac{2123 \pm 62}{265-20}$ & 49 & 31 \\
\hline 0 & 100 & $\frac{410 \pm 12}{512-27}$ & $\frac{1029 \pm 37}{296-18}$ & $\frac{620 \pm 21}{156-10}$ & $\frac{2059 \pm 42}{250-26}$ & 50 & 30 \\
\hline \multicolumn{8}{|c|}{ Humus mass $20 \%$} \\
\hline 80 & 0 & $\frac{148 \pm 5}{185-12}$ & $\frac{487 \pm 17}{140-7}$ & $\frac{567 \pm 14}{154-10}$ & $\frac{1202 \pm 21}{146-13}$ & 40 & 47 \\
\hline 60 & 20 & $\frac{259}{323-27}$ & $\frac{676 \pm 28}{194-11}$ & $\frac{668 \pm 22}{169-11}$ & $\frac{1613}{196-15}$ & 42 & 41 \\
\hline 40 & 40 & $\frac{370 \pm 7}{462-38}$ & $\underline{896 \pm 20}$ & $\frac{741 \pm 24}{187-13}$ & $\frac{2007 \pm 47}{244-23}$ & 45 & 37 \\
\hline 20 & 60 & $\frac{418 \pm 18}{522-18}$ & $\frac{1085 \pm 26}{312-26}$ & $\frac{757 \pm 25}{191-14}$ & $\frac{2323}{282-22}$ & 47 & 33 \\
\hline 0 & 80 & $\frac{561 \pm 19}{645-25}$ & $\frac{1174 \pm 22}{337-33}$ & $\frac{804 \pm 17}{203-42}$ & $\frac{2539 \pm 56}{308-29}$ & 46 & 32 \\
\hline \multicolumn{8}{|c|}{ Humus mass $40 \%$} \\
\hline 60 & $0^{* *}$ & $\frac{208 \pm 5}{260-22}$ & $\frac{640 \pm 14}{184-16}$ & $\frac{750 \pm 18}{189-17}$ & $\frac{1598 \pm 36}{194-19}$ & 40 & 47 \\
\hline 40 & 20 & $\underline{290 \pm} \pm \frac{8}{362-25}$ & $\frac{781 \pm 31}{224-13}$ & $\frac{780 \pm 33}{197-11}$ & $\frac{1851 \pm 62}{225-16}$ & 42 & 42 \\
\hline 20 & 40 & $\underline{380 \pm 8}$ & $\frac{975 \pm 24}{280-23}$ & $\underline{810 \pm 18}$ & $\frac{2165 \pm 50}{263-25}$ & 45 & 37 \\
\hline 0 & 60 & $\frac{500 \pm 9}{625-44}$ & $\frac{1096 \pm 30}{315-23}$ & $\frac{848 \pm 26}{214-16}$ & $\frac{2444 \pm 64}{297-24}$ & 45 & 35 \\
\hline \multicolumn{8}{|c|}{ Humus mass $60 \%$} \\
\hline 40 & 0 & $\frac{280 \pm 6}{350-30}$ & $\frac{760 \pm 22}{218-16}$ & $\frac{832 \pm 21}{210-19}$ & $\frac{1872 \pm 24}{227-33}$ & 40 & 44 \\
\hline 20 & 20 & $\frac{342 \pm 12}{428-21}$ & $\frac{908 \pm 27}{261-19}$ & $\underline{868 \pm 27}$ & $\frac{2118 \pm 48}{257-25}$ & 43 & 41 \\
\hline 0 & 40 & $\frac{400 \pm 10}{500-31}$ & $\frac{1061 \pm 23}{305-27}$ & $\underline{858 \pm 23}$ & $\frac{2319 \pm 17}{281-55}$ & 48 & 37 \\
\hline \multicolumn{8}{|c|}{ Huтиs mass $80 \%$} \\
\hline 20 & 0 & $\underline{351 \pm 9}$ & $\frac{905 \pm 20}{260-24}$ & $\frac{937 \pm 28}{236-18}$ & $\frac{2193 \pm 21}{266-46}$ & 41 & 43 \\
\hline 0 & 20 & $\frac{369 \pm 11}{461-25}$ & $\frac{988 \pm 29}{284-20}$ & $\frac{961 \pm 35}{243-16}$ & $\frac{2318 \pm 42}{281-32}$ & 43 & 41 \\
\hline \multicolumn{8}{|c|}{ Humus mass without sand and loam } \\
\hline 0 & 0 & $\frac{419 \pm 9}{524-36}$ & $\frac{1081 \pm 30}{311-23}$ & $\frac{928 \pm 19}{234-25}$ & $\frac{2428 \pm 31}{295-43}$ & 44 & 30 \\
\hline
\end{tabular}

Note. Table value of quantiles of Student's test $(t)$ at probability level $0.05-2.06$. In the numerator - average biomass of seedlings, in the denominator - the percentage relative to the control and the calculated Student's criterion $\left(t_{p}\right)$ 
The humus mass of gray forest soils and loess loam, altering the mode of moistening of the sandy soils, significantly affects the redistribution of individual parts of the phytomass in annual oak seedlings. It is also worth noting that no visible signs of mycorrhiza settlement were observed on the roots of oak seedlings growing on sandy soils and on loess loam. Oneyear-old oak seedlings growing on sandy soils form rather long (within $41-53 \mathrm{~cm}$ ) rod roots, and the sandy space around them develops an openwork network of suction roots (Fig. 2,a). The architectonics of root systems in oak seedlings undergoes peculiar changes with the increase in the content of humus mass and loess loam in the sand. In particular, the roots of the seedlings take on a wrinkled form and branch more intensively, and on mixtures with an admixture of humus mass on the sucking roots, visually observed cells of mycorrhiza (Fig. 2,b) settle and operate quite effectively. It leads to a redistribution of mass between the underground and aboveground parts of the seedlings.

At the same time, the total phytomass of seedlings in the vast majority of variants did not change significantly, and against the background of the ameliorants, there was a significant decrease in the root mass and an increase in the mass of the assimilation apparatus and stems (Table 4).

Among the three-component mixtures, one should pay attention to the mixture containing $40 \%$ of humus mass, $40 \%$ of sand and $20 \%$ of loam, because it is on this mixture that the

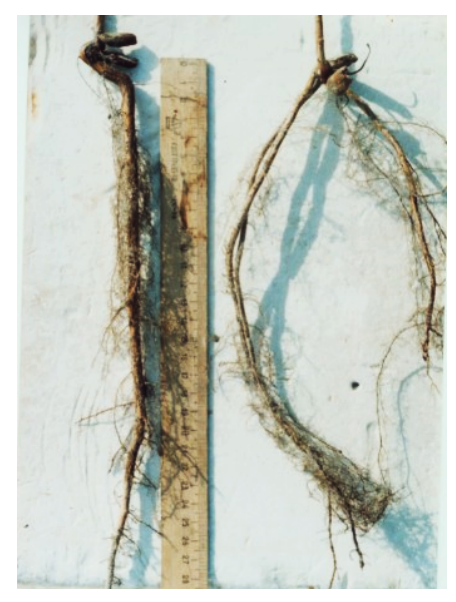

$a$

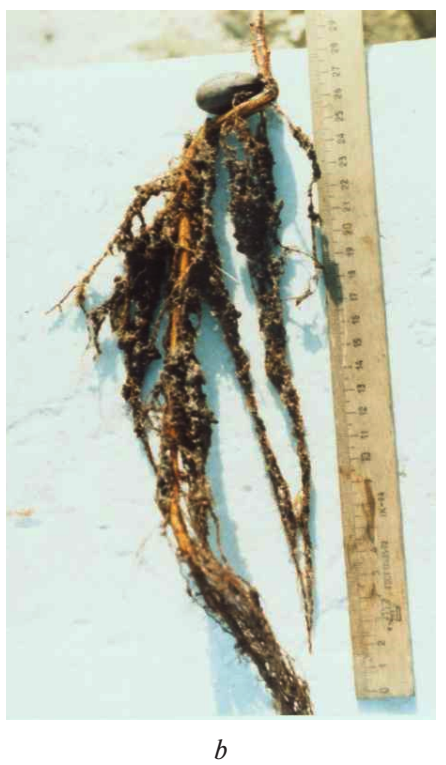

Fig. 2. Root system of annual oak seedlings grown on sandy soils (a) and on sandy soils with $20 \%$ admixture of humus mass of gray forest soils (b) oak seedlings accumulated the same mass as the two-component mixture. However, the mass of aboveground and underground parts in this variant were somewhat different, and their participation in the total mass of stems, leaves and roots was $14.1,15.9$ and $71.0 \%$ respectively. Actually, these two mixtures can be used to optimize the ecological conditions of the recul-

Table 4

Phytomass of annual oak seedlings grown on sandy soils with varying humus mass content of gray forest soils and loess loam

\begin{tabular}{|c|c|c|c|c|c|c|c|}
\hline \multicolumn{2}{|c|}{ Content, $\%$} & \multicolumn{4}{|c|}{ Mass, $\mathrm{g}$} & \multicolumn{2}{|c|}{ Mass, $\%$} \\
\hline चี & ్్ㅀ & stems & foliage & roots & total & $\begin{array}{l}\text { 品 } \\
\stackrel{\Xi}{0} \\
\stackrel{0}{0}\end{array}$ & ڤ̊ \\
\hline \multicolumn{8}{|c|}{ Without humus mass } \\
\hline 100 & $0^{*}$ & $\frac{0.3 \pm \underline{0.01}}{100--}$ & \begin{tabular}{|c|}
$\frac{0.5}{100} 0.01$ \\
$100--$
\end{tabular} & $\frac{8.9 \pm 0.30}{100--}$ & $\frac{9.7 \pm 0.30}{100--}$ & 5.2 & 91.8 \\
\hline 80 & 20 & $\frac{0.8 \pm 0.02}{266-22}$ & $\frac{0.7 \pm 0.01}{140-14}$ & $\frac{8.4 \pm 0.16}{94-2}$ & $\frac{9.9 \pm 0.19}{102-1}$ & 7.1 & 84.8 \\
\hline 60 & 40 & $\frac{1.2 \pm 0.03}{400-28}$ & $\frac{0.7 \pm 0.01}{140-14}$ & $\frac{7.5 \pm 0.16}{84-4}$ & $\frac{9.4 \pm 0.21}{97-1}$ & 7.4 & 79.8 \\
\hline 40 & 60 & $\frac{1.4 \pm 0.03}{467-30}$ & $\frac{0.9 \pm 0.02}{180-18}$ & $\frac{7.1 \pm 0.21}{80-5}$ & $\frac{9.4 \pm 0.24}{97-1}$ & 9.6 & 75.5 \\
\hline 20 & 80 & $\frac{1.5 \pm 0.02}{500-54}$ & $\frac{1.0 \pm 0.02}{200-22}$ & $\frac{6.7 \pm 0.16}{75-6}$ & $\frac{9.2 \pm 0.19}{94-1}$ & 10.9 & 72.8 \\
\hline 0 & 100 & $\frac{1.6 \pm 0.05}{533-26}$ & $\frac{1.1 \pm 0.03}{220-19}$ & $\frac{6.3 \pm 0.70}{71-3}$ & $\frac{9.0 \pm 0.19}{93-2}$ & 12.2 & 70.0 \\
\hline \multicolumn{8}{|c|}{ Humus mass $20 \%$} \\
\hline 80 & $0^{* *}$ & $\frac{0.8 \pm 0.02}{266-22}$ & $\frac{0.7 \pm 0.02}{140-9}$ & $\frac{8.6 \pm 0.25}{97-1}$ & $\frac{10.1 \pm 0.29}{104-1}$ & 6.9 & 85.1 \\
\hline 60 & 20 & $\frac{1.1 \pm 0.04}{367-19}$ & $\frac{1.3 \pm 0.04}{260-19}$ & $\frac{7.8 \pm 0.10}{88-3}$ & $\frac{10.2 \pm 0.13}{105-2}$ & 12.7 & 76.5 \\
\hline 40 & 40 & $\frac{1.4 \pm 0.04}{467-27}$ & $\frac{1.5 \pm 0.05}{300-20}$ & $\frac{7.0 \pm 0.17}{79-6}$ & $\frac{9.9 \pm 0.25}{102-1}$ & 15.2 & 70.7 \\
\hline 20 & 60 & $\frac{1.5 \pm 0.04}{500-29}$ & $\frac{1.5 \pm 0.04}{300-24}$ & $\frac{5.9 \pm 0.10}{66-9}$ & $\frac{8.9 \pm 0.17}{92-2}$ & 16.8 & 66.3 \\
\hline 0 & 80 & $\frac{1.6 \pm 0.03}{533-41}$ & $\frac{1.6 \pm 0.04}{320-27}$ & $\frac{5.3 \pm 0.11}{60-11}$ & $\frac{8.5 \pm 0.14}{88-4}$ & 18.8 & 62.3 \\
\hline \multicolumn{8}{|c|}{ Humus mass $40 \%$} \\
\hline 60 & $0^{* *}$ & $\frac{1.1 \pm 0.03}{367-25}$ & $\frac{0.8 \pm 0.03}{160-9}$ & $\frac{8.6 \pm 0.29}{97-1}$ & $\frac{10.5 \pm 0.31}{108-2}$ & 7.6 & 81.9 \\
\hline 40 & 20 & $\frac{1.4 \pm 0.03}{467-35}$ & $\frac{1.7 \pm 0.10}{340-12}$ & $\frac{7.6 \pm 0.22}{85-4}$ & $\frac{10.7 \pm 0.30}{110-2}$ & 15.9 & 71.0 \\
\hline 20 & 40 & $\frac{1.6 \pm 0.03}{533-41}$ & $\frac{2.1 \pm 0.08}{420-20}$ & $\frac{6.5 \pm 0.20}{73-7}$ & $\frac{10.2 \pm 0.30}{105-1}$ & 20.6 & 63.7 \\
\hline 0 & 60 & $\frac{1.7 \pm 0.03}{567-44}$ & $\frac{2.0 \pm 0.05}{400-29}$ & $\frac{5.4 \pm 0.13}{60-11}$ & $\frac{9.1 \pm 0.24}{94-2}$ & 21.9 & 59.3 \\
\hline \multicolumn{8}{|c|}{ Humus mass $60 \%$} \\
\hline 40 & $0^{* *}$ & $\frac{1.3 \pm 0.04}{433-24}$ & $\frac{1.1 \pm 0.03}{220-19}$ & $\frac{7.8 \pm 0.21}{88-3}$ & $\frac{10.2 \pm 0.24}{105-1}$ & 10.8 & 76.5 \\
\hline 20 & 20 & $\frac{1.7 \pm 0.03}{567-44}$ & $\frac{2.2 \pm 0.07}{440-24}$ & $\frac{6.6 \pm 0.19}{74-6}$ & $\frac{10.5 \pm 0.28}{108-2}$ & 21.0 & 62.8 \\
\hline 0 & 40 & $\frac{1.8 \pm 0.04}{600-36}$ & $\frac{2.8 \pm 0.05}{560-39}$ & $\frac{5.3 \pm 0.10}{60-11}$ & $\frac{9.9 \pm 0.18}{102-1}$ & 28.3 & 53.5 \\
\hline \multicolumn{8}{|c|}{ Humus mass $80 \%$} \\
\hline 20 & $0^{* *}$ & $\frac{1.4 \pm 0.05}{467-22}$ & $\frac{1.2 \pm 0.04}{240-17}$ & $\frac{7.4 \pm 0.18}{83-4}$ & $\frac{10.0 \pm 0.21}{103-1}$ & 12.0 & 74.0 \\
\hline 0 & 20 & $\frac{1.9 \pm 0.05}{633-31}$ & $\frac{2.7 \pm 0.07}{540-31}$ & $\frac{6.1 \pm 0.13}{69-8}$ & $\frac{10.7 \pm 0.22}{110-3}$ & 25.2 & 57.0 \\
\hline \multicolumn{8}{|c|}{ Humus mass without sand and loam } \\
\hline 0 & $0^{*}$ & $\frac{1.6 \pm 0.05}{533-26}$ & $\frac{1.3 \pm 0.05}{260-16}$ & $\frac{6.8 \pm 0.12}{76-6}$ & $\frac{9.7 \pm 0.13}{100-0}$ & 13.4 & 70.0 \\
\hline
\end{tabular}

Note. Table value of quantiles of Student's test $(t)$ at probability level $0.05-2.06$. In the numerator - average biomass of seedlings, in the denominator - the percentage relative to the control and the calculated Student's criterion $\left(t_{p}\right)$ 
tivation layer of sandy soils in the case of growing of mesotrophic wood plants.

Conclusions. It is found that in the case of increase in the content of loams in the sand from 20 to $80 \%$, their density increases by $0.7-4.0 \%$, and the porosity - by $1.6-19.2 \%$. The sand density decreases by $6.0-24.8 \%$ and their porosity increases by $1.1-8.0 \%$ with the increase in the humus mass content of sod-podzolic sandy loam soils. When mixed with sands of these ameliorants (20-80\%), the density of sands decreases by $3.4-20.8 \%$, and other investigated indicators tend to increase. In particular, there is an increase in: the porosity by $22.0-68.9 \%$; moisture content - absolute by $40-560 \%$ and relative by $21.0-442 \%$; the total phytomass of annual pine seedlings - by $40.0-237.0 \%$ and the share of needles in them - by $2.0-8.0 \%$. At the same time, the maximum values of the phytomass were recorded in annual pine seedlings, which grew on a mixture with $20 \%$ humus mass content and $80 \%$ loam.

There are positive changes in the experimental mixtures with the increase in the sand content of loess loam and humus mass of gray forest loam soils from 20 to $80 \%$. The content of absolute and relative moisture increases by $75.0-890.0 \%$ and $61.0-639.0 \%$ respectively and annual oak seedlings growing on these mixtures showed a significant increase in the mass of stems (by 166.0-533.0\%) and leaves (by 40-460\%) and reduction of root mass by 3-40\%. At the same time, the proportion of leaves grows (by 11.9-17.5\%), and the share of roots decreases (by 17-23\%) in the total phytomass of oak seedlings. The highest phytomass values are observed in seedlings that have grown on two mixtures, which contained $40 \%$ humus mass, $40 \%$ sand and $20 \%$ loam, as well as $80 \%$ humus mass and $20 \%$ loam.

It is found that admixture to the sands of humus mass $(20 \%)$ and loess loam $(20 \%)$ significantly affects the phytomass accumulation in woody plants. Such a proportion of these ameliorants should be considered minimal in the case of the formation of a reclamation layer on sandy soils during their phytomelioration. Optimization of forest plant properties on the sands can be achieved by forming a reclamation layer of the following mixtures: for the cultivation of woody oligotrophs $-20 \%$ of the humus mass of sod-podzolic soils and $80 \%$ of loess loams; for the cultivation of woody mesotrophs $-40 \%$ of humus mass of gray forest soils, $40 \%$ of sand and $20 \%$ of loam, or $-80 \%$ of humus mass and $20 \%$ of loam.

\section{References.}

1. The land fund of Ukraine on January 1, 2016 and the dynamics of its changes compared with the data on January 1, 2015 (n.d.). Retrieved from https://land.gov.ua.info/zemelnyifond-na-1-sichna2016-roku-ta-dinamika-ioho-zmin-uporivnanni-z-danumy-na-1-schnia-2015-roku.

2. Martin, A., Osipchuk, S., \& Chumachenko, O. (2015). Natural-agricultural regionalization of Ukraine. Monograph. Kyiv: Komprint.

3. Brovko, F., \& Brovko, D. (2017). Phytomelioration of sandy litosoils of natural and man-made origin: Monograph. Kyiv. Condor.

4. Wang, C., Zhao, C., Xu, Z., \& Wang, Y. (2013). Effect of vegetation on soil water and storage in a semi-arid alpine forest catch merit. Journal of arid land, 5(2), 206-219. https://doi. org/10.1007/s40333-013-0151-5.

5. Dolgova, T. (2008). Features of soil monitoring in mining areas while solving problems of their environmental safety. Naukovyi Visnyk Natsionalnoho Hirnychoho Universytetu, (3), 90-96.

6. Loza, I. M., Pakhomov, O.Y., Chorna, V.I., \& Voroshilova, N. V. (2018). Evaluation of remediation efficiency of manganese quarry lands after open-cut mining: ecosystem approach. Naukovyi Visnyk Natsionalnoho Hirnychoho Universytetu, (4), 122-128. https://doi.org/10.29202/nvngu/2018-4/16.
7. Macdonald, E., Quideau, S., \& Landhauser, S. (2012) Rebulding boreal forest after industrial disturbance. In Restoration and reclamation of boreal ecosystems: attaining Sustainable development. Cambridge University. Press Cambridge, UK. (pp.123160). https://doi.org./10.1017/CBO9781139059152.010.

8. Masyuk, O. M. (2017). Dynamics of formation of grass in the plantations of Hippophae rhamnoides L. on various types of recultivation of disturbed lands of Western Donbass. Issues of steppe forestry and forest recultivation of lands, 46, 64-76.

9. Rowland, S., Prescoft, C., Grayston, S., \& Quideau, S. (2009). Recreating a Functioning Forest Soil in Reclaimed Oil Sands in Northern Alberta: An Approach for measuring success in Ecological Restoration. Journal of Environmental Quality, 38(4), 1580-1590. https://doi.org./10.2134/ieg2008.0317. 10. Chernyavsky, E. A. (2010). Engineering surveys, development and rehabilitation of sand quarries in Western Siberia (on the example of the Thermokarst gas condensate field). Ecology of urbanized territories, 12, 74-80.

11. Izyumova, O. G. (2016). Formation of water-physical properties of soil of re-cultivated territories. Naukovyi Visnyk Natsionalnoho Hirnychoho Universytetu, (1), 85-89.

12. Dhar, A., Comean, P., \& Vasson, R. (2019). Effects of cover soil stockpiling on plant community development following reclamation of oil sand sites in Alberta. Restoration Ecology, 27(2), 352-360. https://doi.org/10.1111/rec.12858.

13. Comean, P., Karst, J., Pinno, B., Chang, S., Naeth, A., \& Vassov, R. (2018). Plant community development following reclamation of oil sands mine sites in the boreal forest: a review. Environmental Reviews, 26(3), 286-289. https://doi. org/10.1139/er-2017-0091.

14. Zhang, J., Ding, Z., \& Mengting, L. (2017). Risk analysis of water searcity in artificial woodlands of senit rid and China. Land Use Policy, 63, 324-330.

15. Mo, K., Cong, Z., \& Lei, Y. (2015). Optimal vegetation cover in the Horgin in Sands, China. Ecohydrology, 9(4), 700711. https://doi.org/10.1002/eco.1668.

16. Wang, C., Zhao, C., Xu, Z., Wang, Y., \& Peng, H. (2013). Effect of vegetation on soil water and stored in a sand-arid alpine forest catchment. Journal of arid land, 5(2), 206-219. https://doi.org/10.1007/s40333-013-0151-5.

17. Chu, J., Ivanov, V., Naemini, M., Stabnikov, V., \& Lie, H. (2014). Optimization of calcium-based bioclgging and biocementation of sand. Acta Geotechnica, 9(2), 277-285.

18. Akça, E., Kapur, S., Tanaka, Y., Kaya, Z., Çetin, H., Bedestenei, H., \& Yakti, S. (2010). Afforestation effect on soil quality of sand dunes. Polish Journal of Environmental Studies, 19(6), 1109-1116.

19. State Standard of Ukraine (n.d.). ISO 11272-2001 Quality of the soil. Determination of drying density on dry weight. Kyiv. 20. State Standard of Ukraine (n.d.). ISO 16586-2005 Quality of soil. Determination of volumetric soil moisture due to known drying density on dry weight. Gravimetric method. Kyiv.

21. Borovikov, V. P. (2013). A popular introduction to the current analysis in the STATISTICA system. Methodology and technology of modern data analysis. Moscow: Hot Line-Telecom.

\section{Оптимізація водно-фізичних властивостей піщаних літоземів природно-техногенного походження}

\section{Ф. М. Бровко, О. Ф. Бровко, С. П. Танчик, В. Ю. Юхновський}

Національний університет біоресурсів і природокористування України, м. Київ, Україна, e-mail: fmbrovko@ukr.net

Мета. Встановити зміни, яких зазнають водно-фізичні властивості піщаних літоземів за різного вмісту в них лесоподібних суглинків, гумусованої маси дерново-підзолистих супіщаних і сірих лісових суглинистих грунтів, по- 
казати їх вплив на нагромадження фітомаси в однорічних саджанцях сосни звичайної та сіянців дуба звичайного.

Методика. Показники щільності, шпаруватості, а також абсолютної й відносної вологості піщаних літоземів і їх сумішей з різним умістом суглинків і гумусованої маси зональних грунтів визначали за загальноприйнятими у грунтознавстві методиками. Вплив досліджених сумішей на водно-фізичні властивості пісків оцінювали за показниками нагромадженої абсолютно сухої фітомаси однорічних саджанців сосни та сіянців дуба звичайного.

Результати. Встановлено, що зі зростанням у піщаних літоземах умісту лесоподібних суглинків і гумусованої маси дерново-підзолистих супіщаних грунтів із 20 до $80 \%$ у їх сумішах простежується зменшення щільності (на 3,4-24,8 \%), збільшення шпаруватості (на 1,1-70,0 \%) та вологості - абсолютної (на 5-560 \%) й відносної (на 11-442\%). Частка хвої в загальній фітомасі саджанців сосни звичайної зростає (на 2-8 \%), а частка коренів зменшується (на 2-18 \%). Однорічні саджанці сосни найбільшу масу (2539 мг) нагромаджували на суміші із $20 \%$ умістом гумусованої маси та $80 \%$ умістом суглинків. Зі збільшенням у пісках умісту лесоподібних суглинків і гумусованої маси сірих лісових суглинистих грунтів із 20 до $80 \%$ абсолютна вологість сумішей зростає на 75,0-870,0 \%, а показники відносної вологості на $61,0-639,0 \%$. У загальній фітомасі однорічних сіянців дуба звичайного частка листя збільшується (на 11,9-15,8 \%), а частка коренів зменшується (на 13,0-22,8 \%). У однорічних сіянців дуба максимальні показники загальної маси $(10,7$ г) спостерігались на сумішах, що містили 40 \% гумусованої маси сірих лісових грунтів, $20 \%$ лесоподібних суглинків і $40 \%$ піску, а також $80 \%$ гумусованої маси та $20 \%$ суглинків.

Наукова новизна. Показано, що 20-80\% домішка до пісків лесоподібних суглинків та гумусованої маси дерново-підзолистих супіщаних грунтів істотно збільшує їх шпаруватість, уміст у них вологи й позитивно впливає на нагромадження фітомаси у однорічних саджанців сосни. Така ж домішка до пісків лесоподібних суглинків і гумусованої маси сірих лісових суглинистих грунтів забезпечує суттєве збільшення абсолютної й відносної вологості в досліджених сумішах і викликає у однорічних сіянців дуба збільшення маси листя та зменшення маси коренів.

Практична значимість. Запропоновані варіанти формування рекультиваційного шару із трикомпонентних сумішей, до складу яких входять пісок, лесоподібні суглинки та гумусована маса зональних грунтів, дозволять оптимізувати водно-фізичні властивості піщаних літоземів природно-техногенного походження. Застосування опрацьованих грунтосумішей забезпечить більш ефективне використання піщаних літоземів у господарських цілях і водночас зменшить прояв процесів водної ерозії та дефляції.

Ключові слова: фітомаса, пісок, суглинок, саджанець, сіянець, щільність, шпаруватість

\section{Оптимизация водно-физических свойств песчаных литоземов природно-техногенного происхождения}

\section{Ф. М. Бровко, О. Ф. Бровко, С. П. Танчик, В. Ю. Юхновский}

Национальный университет биоресурсов и природопользования Украины, г. Киев, Украина, e-mail: fmbrovko@ukr. net
Цель. Установить изменения водно-физических свойств песчаных литозёмов под влиянием различного содержания лессовидных суглинков, гумусированной массы дерново-подзолистых супесчаных и серых лесных суглинистых почв, а также показать их влияние на накопление фитомассы однолетними саженцами сосны обыкновенной и сеянцами дуба обыкновенного.

Методика. Показатели плотности, пористости, а также абсолютной и относительной влажности песчаных литозёмов и их смесей с различным содержанием суглинков и гумусированной массы зональных почв определяли по общепринятым в почвоведении методикам. Влияние исследованных смесей на водно-физические свойства песков оценивали по показателям накопленной абсолютно сухой фитомассы однолетних саженцев сосны обыкновенной и сеянцев дуба обыкновенного.

Результаты. Установлено, что, с увеличением в песчаных литозёмах содержания лессовидных суглинков и гумусированной массы дерново-подзолистых супесчаных почв с 20 до $80 \%$, в их смесях прослеживается уменьшение плотности (на 3,4-24,8 \%), увеличение скважности (на 1,1-70,0 \%) и влажности - абсолютной (на 5-560 \%) и относительной (на 11-442\%). Участие хвои в общей фитомассе саженцев сосны обыкновенной увеличивается на 2-8 \%, а корней уменьшается на 2-18\%. Однолетние саженцы сосны накапливали наибольшую массу (2539 мг) на смеси из $20 \%$ содержанием гумусированной массы и $80 \%$ содержанием суглинков. С увеличением в песках содержания лессовидных суглинков и гумусированной массы серых лесных суглинистых почв с 20 до $80 \%$ абсолютная влажность смесей увеличивается на $75,0-870,0 \%$, а показатели относительной влажности на $61,0-639,0 \%$. В общей фитомассе однолетних сеянцев дуба обыкновенного участие листьев увеличивается на 11,9-15,8\%, а корней уменьшается на $13,0-22,8 \%$. У однолетних сеянцев дуба максимальные показатели общей массы (10,7 г) наблюдались на смесях, содержащих $40 \%$ гумусированной массы серых лесных почв, $20 \%$ лессовидных суглинков и $40 \%$ песка, а также $80 \%$ гумусированной массы и $20 \%$ суглинков.

Научная новизна. Показано, что 20-80 \% примесь лессовидных суглинков и гумусированной массы дерново-подзолистых супесчаных почв к пескам существенно увеличивает их скважность, содержание в них влаги и положительно влияет на накопление фитомассы у однолетних саженцев сосны. Такая же примесь к пескам лессовидных суглинков и гумусированной массы серых лесных суглинистых почв обеспечивает существенное увеличение абсолютной и относительной влажности в исследованных смесях и вызывает у однолетних сеянцев дуба увеличение массы листьев и уменьшение массы корней.

Практическая значимость. Предложенные варианты формирования рекультивационного слоя из трехкомпонентных смесей, в состав которых входят песок, лессовидные суглинки и гумусированная масса зональных почв, позволят оптимизировать водно-физические свойства песчаных литозёмов природно-техногенного происхождения. Применение разработанных смесей обеспечит более эффективное использование песчаных литозёмов в хозяйственных целях и одновременно уменьшит проявление процессов водной эрозии и дефляции.

Ключевые слова: фитомасса, песок, суглинок, саженеи, сеянеи, плотность, скважность

Recommended for publication by V. P. Shlapak, Doctor of Agricultural Science. The manuscript was submitted 28.08.18. 